\title{
Learning Outcomes and the Success of Entrepreneurs: The Case of Vietnam
}

Received: 18.08 .2021

Available online: 28.12 .2021

\section{Cuong Tat Do*}

\section{Abstract}

This paper aims to analyze the effect of investing in balanced skills on the probability of success of entrepreneurs within the context of Vietnam. By not taking this possible linkage into account, previous researchers have underestimated the effect of general and specialized skills as learning outcomes from formal schools and higher education institutions on the probability of success of entrepreneurs. Additionally, the effect of balanced skills - a combination of general and special skills - on the probability of success of entrepreneurs in Vietnam does has not attracted much of scholars' and policy makers' attention. Data provided by GEM helps this paper analyze the effects of learning outcome and balanced skills on the probability of success of entrepreneurs. The empirical results support the theory of entrepreneurship that invests more first in general, special skills and then balanced skills will increase the chance of success of entrepreneurs.

Key words: Entrepreneur, balanced skills, occupational choice, human capital, Vietnam

JEL: E24, H41

\section{Introduction}

Jow does education attainment enhance the success of entrepreneurs? The answer economists give to this question is that entrepreneurs choose their career path by comparing their costs and benefits of alternative occupations. In the classical Lucas Jr (1978) and (Rosen, 1982) model of career selection, agents with higher managerial skills - defined as ability to produce more output from a given combination of inputs will move into entrepreneurship because they see a chance to have higher income from a managing position than the wage they can earn as employees. Entrepreneurial skills can be referred to a wider range than managerial skills to include: (i) the ability to manage risk; (ii) the ability to recognize economic opportunities; and (iii) the ability to enhance the success of business through a process of creating a new product (Guiso, Pistaferri, \& Schivardi, 2021). Obtaining these abilities by entrepreneurs from learning process or inheriting is still not clearly explained. It is important to understand that entrepreneurial skills are obtained mainly from the learning process or are innate characteristics.

An entrepreneur is defined as an individual that has the following abilities: (i) to make business plans, organize and control the

\footnotetext{
Ho Chi Minh National Academy of Politics. This research is funded by Ministry of Education and Training of Vietnam under the Grant number CT.2019.07.04.
} 


\section{Articles}

business (Mohanty, 2005; Nandan, 2013; Viramgami, 2007); (ii) to maximize business opportunities (Bessant \& Tidd, 2007; Drucker, 2014); (iii) to make the initiatives, tolerate the risk of failure and frame the socio-economic mechanism (Shapero \& Sokol, 1982; Ulhøi, 2005); and (iv) to perform as a leader and an innovator (Hébert \& Link, 2006; Schumpeter, 1982). The success of entrepreneurs is defined as the success of establishing new companies (Boldureanu, lonescu, Bercu, Bedrule-Grigoruţă, \& Boldureanu, 2020).

Guiso et al. (2021) distinguish between these two sources of entrepreneurial skills. These authors argue that if entrepreneurial ability is innate then its distribution should be consistent among different groups of population and differences between entrepreneurship across countries and regions should be traced back to factors that encourage or discourage people from having entrepreneurial ability to set up a firm - for instance, capital or institutional frictions. Consequently, to foster entrepreneurship requires to remove all these obstacles. On the other hand, if entrepreneurial ability can be obtained through learning, the differences in entrepreneurship among countries and regions can partly reflect the differences in the learning environment or process (Dickson, Solomon, \& Weaver, 2008); it means that learning frictions are constraints to entrepreneurship. Therefore, these obstacles can be removed by improving the learning process.

In this paper, the author investigates the effect of learning outcomes - measured by schooling years and working experiences - on the probability of the success of entrepreneurs. While individuals can enhance their chance to become successful entrepreneurs through their preparation in previous years
Learning Outcomes and the Success of Entrepreneurs:

The Case of Vietnam

of schooling. Arguably, an entrepreneur who has better learning outcomes might have a higher probability of success than the other with the lack of chance to access the learning process; it also means that an individual living in Hanoi can have a better chance to have successful entrepreneurship than an individual living in the other province that has poorer conditions. This situation might be caused by the high concentration of entrepreneurial activities in Hanoi and provides many direct or indirect learning opportunities to the fortunate individual than the other who is living in a place with poorer conditions. If there is a case, enhancing the learning process or providing better access to the learning process to everyone could be a potential solution. This study aims to identify whether these intuitive predictions have empirical support. In particular, this paper tests whether formal learning in schools or universities and informal learning affects the probability of success of the choice to become an entrepreneur and their implications for policy reform.

This paper employs Lucas Jr's (1978) and Lazear's (2004) frameworks as a major theoretical background. The learning process can affect the probability of success of entrepreneurs through three channels. First, individuals can choose their entrepreneurial career based on their evaluation of potential income. Lazear (2004) shows that individuals choose their career by analyzing their two directions that might influence their decision: (i) working for the other requires them to focus on specializing in one skill; and (ii) becoming an entrepreneur requires to focus on the weakest skill. For the other two channels, this paper extends and adjusts Lucas Jr's (1978) occupation choice model. Second, after deciding to become an entrepreneur, an individual can learn skills that are useful 


\section{Articles}

to run a business (ability to identify "future opportunity" channel). Third, they can learn how to set up a business (ability to overcome their "fear" to do business). It is expected that the first channel will be directed by formal learning at the school or university of the entrepreneurs, while the last two channels show us that the probability of success of the entrepreneurs will be affected by renovating and transforming common knowledge from schools and universities to actual activities. However, the last two channels also show that they might affect the performance of entrepreneurs in different paths: (i) the ability to identify "future opportunities" implies that the average entrepreneurs are more capable of having higher income through their better chance to learn within their networks; while (ii) their "fear" might constrain them to grasp their chances and transform them into entrepreneurial activities.

This research studies the effect of learning on successful of entrepreneurs using the Global Entrepreneurship Monitor (GEM) dataset for Vietnam from 2013 to 2017, where the dataset from 2013 to 2016 is provided by GEM and the dataset for 2017 is provided by the Vietnam Chamber of Commerce and Industry (VCCI). These datasets provide rich information about demographic variables and other information about entrepreneurial skills variables that allow the author to capture the effect of learning to the success of the entrepreneurs. Consequently, it allows the author to test the two implications of the learning model: (i) it is conditional on developing an entrepreneur; (ii) entrepreneurs learning outcomes should have an earlier effect on their decision to become an entrepreneur. The second implication implies to the policy maker that educational policy needs to change in order to foster the success of entrepreneurs in their early stage of learning rather than in the later stage.

The paper contributes to several aspects to literature. Closest to this work is the study of the effect of human and social capital to the success of the entrepreneurs who own their firms. Santarelli and Tran (2013) show that human capital - measured by professional education, start-up experience and learning can be used to predict the successful of firms where learning has the most significant effect. This paper, however, shows the different outcome (effect of learning on the success of the entrepreneurs rather than firms). The fact that, despite these differences, the results are consistent across the two studies points to the importance of learning to the career choice and outcomes. A. T. Nguyen, Do, Vu, Dang, and Nguyen (2019) study the factors affecting the entrepreneurs' intention, and they focus on identifying factors that might affect the choice of school students to become entrepreneurs. Based on their analysis they propose three policies including: (i) supplying innovative educational support for youth entrepreneurs; (ii) developing youth-oriented-policies; and (iii) organizing business contests in schools. Like their paper, this paper proposes several policy implications based on empirical results where the Vietnamese government should provide further transformation of their administrative power in schools and universities to allow educational agents more autonomy in integrating entrepreneurial skills development programs into formal educational curriculums.

The rest of the paper is organized as follows. Section 2 presents a brief review of the relevant literature, while section 3 outlines the research in the context of Vietnam. In section 4 , this paper will provide a simple theoretical framework of the relationship between learning and the success of entrepreneurs. 


\section{Articles}

This generates two testable predictions: (i) higher learning opportunities increase the probability of success of entrepreneurs; and (ii) the probability of success of entrepreneurs is increased whenever entrepreneurs have the ability to shift their learning opportunities. In section 5, this paper discusses identification strategy and presents the data. The results of empirical analysis and its discussion are provided in section 6 . Section 7 provides a discussion and section 8 a conclusion.

\section{A brief of literature review}

\subsection{Description of Vietnamese Entrepreneurs}

According to Ramamurthy (2001), a typical urban entrepreneur in Vietnam is described as a middle-aged person with at least ten years of education and previous employment in a managerial position. On the contrary, Ronnas and Ramamurthy (2001) describe the typical rural entrepreneur as a middle-aged person with less years of schooling (about seven) and prior experiences working as a manager. The prior experience of Vietnamese entrepreneurs, in fact, has been a major cause of a successful entrepreneurs' career.

Q. A. Nguyen and Mort (2016) show that Vietnamese entrepreneurs utilize their own relationship and private connections to develop their firms during the period of Doimoi in Vietnam. Ronnas (2001) demonstrated that the utilization of personalized and informal linkages is the major workhorse among Vietnamese urban entrepreneurs. These findings are similar to the work of the Global Entrepreneurship Monitor and VCCl (2018). T. H. Nguyen, Alam, and Prajogo (2008) find that those entrepreneurs sometimes have credited for finance from their informal networks or private lenders. The Vietnamese small and medium enterprises put more effort
Learning Outcomes and the Success of Entrepreneurs:

The Case of Vietnam

into accessing credit provided by financial institutions than larger or state-owned enterprises.

Young (2009) finds the similar Vietnamese entrepreneurs' characteristics when the author focuses on hospitality and construction industries. The researcher shows that within these two industries, those entrepreneurs can see the new business opportunities by capturing the change of the economic context in Vietnam. Entrepreneurs in the two industries have well exploited the business opportunities brought by the new stage of economic development and the new phase of the international integration of Vietnam.

\subsection{Critical success factor}

Krasniqi and Tullumi (2013) randomly select 256 business start-ups in Kosovo to analyze the critical success factors affecting the success of small firms. According to the two authors, there are four groups of factors including: (i) personal characteristics, social connection and reputation; (ii) management skills; (iii) social and market support; and (iv) institutions. These findings are supported by identifying critical areas for successful firms (Rockart, 1979), critical managerial planning and an action plan to achieve success (Saraph, Benson, \& Schroeder, 1989), focusing on high performance managerial areas (Boynton \& Zmud, 1984).

Another branch of literature on the success of entrepreneurs claims that the success of entrepreneurs could be expressed through the success of their firms. Therefore, researchers pay much attention to the explanation of internal and external factors affecting the success of firms. For example, studies in transition economies provide solid evidence on the role of institutional factors to the success of entrepreneurs and their firms (Chu, Benzing, 


\section{Articles}

\& McGee, 2007; Welter \& Smallbone, 2011). In a study of Romanian entrepreneurs Benzing, Chu, and Bove (2005) show that the top three critical success factors of small firms include: (i) friendliness to consumers; (ii) loyalty and honesty; and (iii) good customer services. Pratt (2001) demonstrates that for the case of Kenyan entrepreneurs, there are four critical success factors of successful entrepreneurs including: (i) availability of capital; (ii) owning business skills; (iii) gaining previous business experience; and (iv) family support. Krasniqi (2012) argues that to achieve success entrepreneurs need to have a balanced alignment between internal (for example: entrepreneurs and managerial skills, etc.) and external factors (for example: family support, institutional factors, etc.).

\section{Research context in Vietnam}

Vietnam has a long history of development of entrepreneurship with different stages.

Q. A. Nguyen and Mort (2016) provide a deep analysis of the development of entrepreneurship in Vietnam before 2013, so this section presents further analysis for the period after 2013. Entrepreneurs in Vietnam for the period after 2013 have developed significantly and provide thousands of jobs for Vietnamese workers. During the years 2013 and 2017, Vietnam participated in the global entrepreneur monitor survey. This survey provides rich information on the development of Vietnamese entrepreneurship. According to the Vietnam GEM report from 2013 to 2017, entrepreneurial conditions in Vietnam improved considerably. Among the 12 indicators of these conditions, Vietnam had three highest ranking indicators including: (i) internal market dynamics (5/54); (ii) cultural and social norms (6/54); and (iii) infrastructure (10/54). Three support indicators that were lowest in ranking include: (i) finance (39/54); (ii) education - post school (40/54); and (iii) governmental programs (43/54) (Table 1).

Table 1. Ranking entrepreneurial conditions in Vietnam 2013 - 2017

\begin{tabular}{|l|c|c|c|c|c|c|}
\hline \multirow{2}{*}{\multicolumn{1}{|c}{ Entrepreneurial conditions }} & \multicolumn{2}{c|}{2013} & \multicolumn{2}{c|}{2015} & \multicolumn{2}{c|}{2017} \\
\cline { 2 - 7 } & Score & Ranking /69 & Score & Ranking /62 & Score & Ranking /54 \\
\hline Internal market - dynamics & 3.50 & 15 & 3.59 & 11 & 4.15 & 5 \\
\hline Cultural and social norms & 3.10 & 20 & 3.23 & 14 & 3.62 & 6 \\
\hline Physical infrastructure & 3.58 & 43 & 4.07 & 17 & 4.19 & 10 \\
\hline Internal market - Openness & 2.66 & 32 & 2.51 & 28 & 2.79 & 12 \\
\hline National policy - general policy & 2.89 & 20 & 2.78 & 15 & 2.40 & 13 \\
\hline National policy - regulation & 2.77 & 13 & 2.62 & 25 & 3.05 & 25 \\
\hline R\&D transfer & 2.54 & 20 & 2.33 & 30 & 2.19 & 34 \\
\hline Education - primary \& secondary & 1.97 & 46 & 1.57 & 47 & 1.83 & 34 \\
\hline Commercial infrastructure & 2.89 & 45 & 2.93 & 42 & 2.82 & 36 \\
\hline Finance & 2.40 & 42 & 2.12 & 50 & 2.27 & 39 \\
\hline Education - Post school & 2.64 & 50 & 2.53 & 47 & 2.61 & 40 \\
\hline Governmental programs & 2.50 & 38 & 2.14 & 50 & 2.09 & 43 \\
\hline
\end{tabular}

Source: Global Entrepreneurship Monitor (2013, 2015, 2017) 


\section{Articles}

\section{Awareness of business opportunities}

Based on the GEM survey from 2013 to 2017 , the proportion of adults who perceive an opportunity to start a new business in Vietnam, after rising sharply to $56.8 \%$ in 2015 (ranked 9/60), has fallen to $46.4 \%$ in 2017 , ranked 23 among 54 economies. Although this rate has decreased compared to 2015, but increased compared to the years 20132014, which is in line with the increasing trend of these years. As a consequence, it seems that the increase rate of 2015 is just an increase and the beginning of a new wave of startups in Vietnam in recent years. The rate of awareness of business opportunities in Vietnam in 2017 is still higher than the average level of countries in a similar stage of development as Vietnam (Global Entrepreneurship Monitor \& VCCI, 2018).

\section{Perception of entrepreneurship}

In 2017, the proportion of adults surveyed in Vietnam who self-assessed that they have the necessary knowledge, skills and experience to start a business still tended to decrease, from $58.2 \%$ in 2014 to $56.8 \%$ in 2015 and $53 \%$ in 2017. Additionally, the percentage of Vietnamese people who are confident in their business ability has decreased compared to 2014 and 2015 despite the increasing number of training programs for starting a business. This trend shows the increasing of competition among Vietnamese entrepreneurs following the changing in business in the new context where the Vietnamese economy is increasingly integrating deeply into the world economy (Global Entrepreneurship Monitor, 2013, 2015, 2017; Global Entrepreneurship Monitor \& VCCl, 2018). However, the percentage of Vietnamese entrepreneurs who self-assessed themselves to have a business ability is still lower than the average
Learning Outcomes and the Success of Entrepreneurs:

The Case of Vietnam

of developed countries when they were in similar development conditions to Vietnam (53.8\%) (Global Entrepreneurship Monitor \& VCCI, 2018).

\section{Intention to start a business}

In Vietnam, the proportion of people who intend to start a business has continued to increase since 2014, reaching $25 \%$ in 2017 , ranking $19^{\text {th }}$ out of 54 economies (Global Entrepreneurship Monitor \& VCCl, 2018). This implies that 1 in 4 people intend to start a business within the period of 3 years in Vietnam. Therefore, the percentage of people intending to start a business in Vietnam in the coming years might still be low and it is necessary to implement public policies to encourage potential entrepreneurs to establish their own business, especially through capacity building training, education and training, equipping adults with business start-up skills, information and knowledge in Vietnam.

\section{Societal values about entrepreneurship}

In the period of 2013 - 2017, the GEM surveys show that the percentage of people who wish to become entrepreneurs has decreased to only $62 \%$ in 2017 , after increasing in the period 2013-2015, from 63\% to $73 \%$ (Global Entrepreneurship Monitor \& VCCl, 2018). This trend implies that after a boom of entrepreneurship in Vietnam, the potential entrepreneurs think more carefully about their intention to choose this career path. Entrepreneurs need to have the necessary skills that they can obtain from formal education at the schools and universities and the relevant business skills. Indeed, in Vietnam, choosing the career path of entrepreneurs is still a courageous decision no matter what they do or do not have entrepreneurial skills. 


\section{Articles}

\section{Theoretical framework}

Based on the analysis of Lazear (2004), the theoretical framework of this paper is the following. Those who work for companies can specialize in a specific set of skills, while entrepreneurs are bounded by their weakest skills. Let there be two sets of skills, $S_{1}$ and $S_{2}$, which originated from formal education, from schools and universities, and from informal education, from working experience, learning from the network, and short-term training. Consequently, the income of specialists and entrepreneurs are presented by:

(i) the income of specialists $=\max \left[S_{1}, S_{2}\right]$ and

(ii) the income of entrepreneurs $=\alpha \min \left[S_{1}, S_{2}\right]$

Where $\alpha$ is a determined parameter of the market where the price of entrepreneurial skills is set at the equilibrium of demand and supply of these skills. This formulation captures the reality that entrepreneurs must be excellent at a set of entrepreneurial skills to operate a business together. Entrepreneurs have obtained these skills from schools, universities, their peers and business experience. Thus, expression (i) and (ii) can be transformed into the following:

(a) the income of specialists $=\max \left[\mathrm{S}_{1}, \mathrm{~S}_{2}\right] \leftarrow$ obtained from schools, universities and experience.

And (b) the income of entrepreneurs $=\operatorname{amin}\left[S_{1}\right.$, $\left.\mathrm{S}_{2}\right] \leftarrow$ obtained from schools, universities, their peers and business experience (Laguna-Sánchez, Abad, de la Fuente-Cabrero, \& Calero, 2020).

Individuals are endowed with their basic talent, but they can enrich their talent via the learning process. $S_{1}^{0}$ and $S_{2}^{0}$ are the initial set of skills $S_{1}$ and $S_{2}$, while $S_{1}$ and $S_{2}$ are final set of skills that obtained from these above sources. Let the individual gain levels $S_{1}$ and $S_{2}$, given the initial set of skills according to the cost function:
$C\left(S_{1}, S_{2}, \mathrm{~S}_{1}^{0}, \mathrm{~S}_{2}^{0}\right)$ with $C_{1}>0, C_{2}>0, C_{i j}>0$

Where $C_{1}$ is the cost function for obtaining set of skills $S_{1}, C_{2}$ is the cost function for obtaining set of skills $S_{2}$, and $C_{i j}$ is cost function of having initial set of skills $S_{1}^{0}$ and $\mathrm{S}_{2}{ }^{0}$.

Let $S_{1}$ be the set of skills that the individual is endowed with. It is assumed that $C_{1}$ is not too much larger than $C_{2}$ at the endowment point. The individual who plans to have better $S_{1}$ will likely invest in $S_{1}$ so as to obtain:

$$
\max _{S_{1}}\left[S_{1}-C\left(S_{1}, S_{2}\right)\right]
$$

With first-order condition

$$
1-C_{1}\left(S_{1}, S_{2}\right)-0
$$

Someone who plans to specialize their skills will invest in one of the two sets of skills. There is waste of resources to augmenting a set of skills that will not be used. It is possible that if $C_{2}$ is sufficiently low relative to $C_{1}$ then the individual might ignore his higher endowment of $S_{1}$ and specialize to $S_{2}$ instead. This reverse decision is not really important because these two ways imply that the individual will likely invest in one set of skills but not both.

Now consider an individual who wishes to become an entrepreneur. His constraint is his minimum set of skills, defined to be $S_{2}$. Which set of skills $-S_{1}$ or $S_{2}$ - should a promising entrepreneur invest in or in both?

Since the constraint is the set of skill $S_{2}$, there is not a wise decision when an individual chooses to invest in $S_{1}$. Thus, the individual invests in $S_{2}$ so as to obtain:

$$
\min \left[S_{1}-C\left(S_{1}, S_{2}\right)\right]
$$
$S_{2}$

With first-order condition

$$
\alpha-C_{2}\left(S_{1}, S_{2}\right)-0
$$




\section{Articles}

There are two possibilities that should be addressed. Firstly, if $C_{2}\left(\mathrm{~S}_{1}^{0}, \mathrm{~S}_{2}{ }^{0}\right)>\alpha$ then the entrepreneur does not invest in his stock of skill $S_{2}$. Secondly, if $C_{2}\left(\mathrm{~S}_{1}^{0}, \mathrm{~S}_{2}{ }^{0}\right)<\alpha$ and $C_{2}\left(\mathrm{~S}_{1}{ }^{0}, \mathrm{~S}_{2}{ }^{0}\right)>\alpha$ then his has the incentive to invest in stock of skill $S_{2}$. In this case, entrepreneurs differ from specialists only in investment decision. Finally, if $C_{2}\left(\mathrm{~S}_{1}^{0}, \mathrm{~S}_{2}{ }^{0}\right)<\alpha$ and $C_{2}\left(\mathrm{~S}_{1}^{0}, \mathrm{~S}_{2}{ }^{0}\right)<\alpha$, then the individuals will invest in one set of skills in attaining the other set of skills. The optimum point of these investment activities will be attained when the individuals have $S_{1}-S_{2}$. In this case, the individual investment does not look like a specialist; he chooses to invest in more than one set of skills.

When entrepreneurs start with $S_{1}>S_{2}$, they will invest in $S_{2}$, and they will stop to invest when they reach an optimum point (Hsieh, Parker, \& van Praag, 2017; Lazear, 2004). They do not look like specialists when they monotonously invest in their strong set of skills. If becoming entrepreneurs is a career path, then entrepreneurs must invest in their skills in order to achieve their success later. However, entrepreneurs do not know that their investment guarantees their success (Hsieh et al., 2017). Their expectation is that investment in skills will increase the probability of success in their career path (Chen \& Thompson, 2016). There are two important questions that will be addressed by this paper:

(i) How much learning outcomes increase the probability of the entrepreneurs' success in their later life?

(ii) Do these investment decisions ensure the success of entrepreneurs?

It is assumed that specialists and entrepreneurs know how to increase their chance to succeed based on their ability to gain further knowledge after leaving schools, universities and the opportunity to acquire
Learning Outcomes and the Success of Entrepreneurs:

The Case of Vietnam

business knowledge and skills from their social relationship. Indeed, they can prioritize their preferences to learn and gain more knowledge or skills through an informal learning process. The ability and strategy of learning can be utilized to distinguish specialists and entrepreneurs. Those who are going to become specialists invest in only one set of skills. Those who become entrepreneurs may invest in one set of skills only if they wish to invest in the weak set of skills. Entrepreneurs invest in more than one set of skills where they seek to invest in a balanced set of skills rather than an unbalanced one.

\section{Empirical method and data}

\subsection{Empirical method}

A natural choice of estimator in this context is the conditional logit (Chamberlain, 1980; Chen \& Thompson, 2016; Lazear, 2004),

$$
\begin{aligned}
\operatorname{Pr}\left(y_{i}\right. & \left.=1 \mid x_{i}\right)=\pi_{i}=\frac{1}{1+e^{-\alpha_{j}-x_{i}^{\prime} \beta}}, i= \\
& =1,2 \ldots, n ; j=1,2, \ldots k
\end{aligned}
$$

where $y_{i}=1$ if individual $i$ successfully establishes a firm, and $y_{i}=0$ otherwise, $x_{i}$ is a vector of individual characteristics and learning outcomes. Uniquely among common estimators, the logit provides consistent estimation of ? despite the choice-based sampling (Prentice \& Pyke, 1979).

For the logit model, it is possible to rewrite it (1) as

$\log \frac{p_{i}}{1-p_{i}}=\alpha+x_{i}^{\prime} \beta$

where $p_{i}=\pi_{i}$. The left-hand side of equation (2) is referred as log odds ratio, and the righthand side of the equation is independent variables. 


\section{Articles}

To analyze the effect of the two sets of skills on the success of entrepreneurs, this paper employs the following econometric specification:

$$
\begin{aligned}
\ell= & \log \frac{p_{i}}{1-p_{i}}=\alpha+\beta_{j} S_{i, j}^{1}+ \\
& +\beta_{k} S_{i, k}^{2}+\beta_{h} Z_{h}+\varepsilon_{i} \\
\ell= & \log \frac{p_{i}}{1-p_{i}}=\theta_{0}+\theta B S_{i}+ \\
& +\theta_{h} Z_{h}+\epsilon_{i}
\end{aligned}
$$

where $S_{i, j}^{1}$ measure skills that individual $i$ obtained from schools in different level $j$ of schooling ranged from secondary school to university. Years of schooling of individual $i$ is utilized to measure the general foundation of skills. These general skills are the first foundation for individuals to select their path: (i) enter universities for acquiring further and deeper skills; (ii) stop learning and start to work as entrepreneurs; and (iii) specializing in skills for their employment. $S_{i, k}^{2}$ measures skills that individual $i$ obtained from outside educational institutions, $k$ is the number of skill category. The set of skills $S_{i, k}^{2}$ include entrepreneurs' networking, ability to see business opportunities, and knowledge to start a business. Balanced skill (BS) in the equation (4) is a combination of $S_{i, j}^{1}$ and $S_{i, k}^{2}$ where the variable gains value 1 if the entrepreneurs have all sets of skills and gains value 0 otherwise.

$$
\alpha, \beta_{j}, \beta_{k}, \theta_{0}, \theta, \theta_{h} \quad \text { are unknown }
$$
parameters. These parameters provide information on the effect of the general foundation and entrepreneurial skills on the probability of entrepreneurs' success. $\varepsilon_{i}, \epsilon_{i}$ are error terms.

\subsection{Data}

\subsubsection{Sample}

Vietnamese entrepreneur data used throughout this research is taken from the GEM database for year 2013 - 2015, and from the Vietnam Chamber of Commerce and Industry for the year 2017, where each wave has around 2000 adult people. This dataset is claimed as the world's most important study of entrepreneurship (Velilla, 2018), which provides a rich sources of data on entrepreneurial activities (Bosma \& Schutjens, 2011; Velilla, 2018) and instruments to construct a balanced skills variable. The GEM database contains information about whether individuals are successful to establish a firm. According to the sample, there are 1,943, 2,000, 2,000 and 2,118 Vietnamese adults in the wave 2013, 2104, 2015 and 2017 respectively; it means that there are 8,061 adults participating in the four waves. Among those participants, the ratios of female to male adults are 1,03,1,03,1,06 and 1,05 for the year 2013, 2014, 2015 and 2017 respectively. It implies that female adults tend to participate in entrepreneurial activities more than male adults.

An advantage of these data is that, consistent with the theory presented in the previous section, the survey respondents are homogenous in terms of education levels. They differ, however, in terms of their absorbed skills after they left educational institutions. Moreover, the data provides rich enough information to calculate the balanced skills based on an assumption that individual investment in balanced skills can be measured through several indicators such as: (i) their knowing about the other entrepreneurs; (ii) their ability to see business opportunity; (iii) have skills to start a new business. The 


\section{Articles}

absence of instrumental variables in the GEM dataset affects the selection of variables capturing investment of entrepreneurs in balanced skills, while variables measuring the successful of entrepreneurs are not affected. Consequently, this paper cannot escape from the endogeneity bias because of the problem related to selection bias. However, according to Hsieh et al. (2017), this limitation is a difficult one to tackle by many empirical researchers in this area, including in this paper.

\subsubsection{Variables}

Success of entrepreneurs: following Hsieh et al. (2017), this paper operationalizes the definition of success of entrepreneurs as the success of the established firm. This variable is utilized as a dependent variable. This variable is 1 if individuals' success to establish a firm and operate it in a period of time and is 0 if otherwise. This choice is following many scholars' specifications on measuring the success of entrepreneurship (Astebro, Chen, \& Thompson, 2008; Elfenbein, Hamilton, \& Zenger, 2010; Folta, Delmar, \& Wennberg, 2010; Hsieh et al., 2017; Nanda \& Sørensen, 2010). Åstebro and Thompson (2011) find that there is no difference between the measurement of entrepreneurship via self-employment, business establishment and business ownership.

Skill balance: this paper's objective is to measure choices of skill balance prior to establishing a firm of entrepreneurs or during the time of their work. This paper's balanced skill variable is computed as a logarithm of the product of two underlying measurements. The first measurement, "General skills", captures the outcome of general education measure via years of schooling. The second measurement, "Specialist skills", captures two aspects: (i) outcomes of higher education -
Learning Outcomes and the Success of Entrepreneurs:

The Case of Vietnam

measure via years of schooling; and (ii) the entrepreneurial skills that are mentioned above. It is said that "General skills" and the first aspect of "Specialist skills" are less scarce to acquire than the second aspect of "Specialist skills". A particular individual can easily enroll in an educational institution to learn, while it is more difficult to learn how to know other entrepreneurs and to gain the ability to see business opportunity or to acquire the skills to start a new business.

"General skills" and "Specialized skills": In this paper, "General skills" measure the total years in school of the individuals. It is said that, "General skills" originates from general education institutions where individuals gain general knowledge and foundational skills from curriculums and the other learning materials and activities. "Specialized skills" originates from the two sources. The first source comes from learning activities in the higher education institutions. Higher education institutions are specialized into different categories such as economics, engineering, IT, journalism, and so on. These institutions provide specialized training courses to their students. Thus, when individuals accept their admission to study at the higher education institutions they choose to invest in specialized skills. The second source of "Specialized skills" comes from the outside world of the individuals. It is said that, the source might be from other entrepreneur in their network or relationship; or their ability to see business opportunities, which might be attributed to their inherent qualities or to their business experience; or their skills to start a business or firm. In this paper, an individual is thought to invest in "Specialized skills" only if the individual has at least one of three elements of the set of specialized skills. It implies that "specialized skills" variable will have four values: (i) equal to 0 if an individual 


\section{Articles}

does not have any special skill; (ii) equal to 1 if an individual has only one specialized skill; (iii) equal to 2 if an individual has any two specialized skills; and (iv) equal to 3 if an individual has three specialized skills.
Control variables: besides key variables, this paper employs a set of control variables including gender, age (from 18 to 64), household income level (measured on 1-3 scale), and the household's size.

Table 2. Descriptive statistics of the key and control variables

\begin{tabular}{|c|c|c|c|c|c|}
\hline Variable & N & Mean & Standard Deviation & Min & Max \\
\hline \multicolumn{6}{|l|}{ Established firm (dummy) } \\
\hline 2013 & 1,943 & 0.187 & 0.390 & 0 & 1 \\
\hline 2014 & 2,000 & 0.162 & 0.369 & 0 & 1 \\
\hline 2015 & 2,000 & 0.261 & 0.439 & 0 & 1 \\
\hline 2017 & 2,118 & 0.208 & 0.406 & 0 & 1 \\
\hline \multicolumn{6}{|l|}{ General skills (years of schooling) } \\
\hline 2013 & 1,044 & 9.534 & 3.506 & 1 & 12 \\
\hline 2014 & 1,045 & 9.345 & 3.625 & 1 & 12 \\
\hline 2015 & 1,109 & 10.169 & 2.745 & 1 & 12 \\
\hline 2017 & 1,049 & 9.796 & 2.696 & 1 & 12 \\
\hline \multicolumn{6}{|l|}{ Specialized skills } \\
\hline \multicolumn{6}{|c|}{ - First aspect (total years from school to higher education) } \\
\hline 2013 & 899 & 16.096 & 0.427 & 12 & 18 \\
\hline 2014 & 955 & 16.058 & 0.338 & 16 & 18 \\
\hline 2015 & 891 & 16.054 & 0.324 & 16 & 18 \\
\hline 2017 & 1,069 & 15.418 & 1.099 & 14 & 22 \\
\hline \multicolumn{6}{|c|}{ - Second aspect (entrepreneurial skills) } \\
\hline 2013 & 1,943 & 1.411 & 0.994 & 0 & 3 \\
\hline 2014 & 2,000 & 1.457 & 0.966 & 0 & 3 \\
\hline 2015 & 2,000 & 1.776 & 0.826 & 0 & 3 \\
\hline 2017 & 2,118 & 2.122 & 0.740 & 1 & 3 \\
\hline \multicolumn{6}{|l|}{ Balanced skill } \\
\hline 2013 & 1,465 & 3.074 & 0.526 & 2,197 & 3,989 \\
\hline 2014 & 1,637 & 2.874 & 0.876 & 0 & 3,989 \\
\hline 2015 & 1,877 & 3.035 & 0.651 & 0 & 3,989 \\
\hline 2017 & 2,118 & 3.115 & 0.617 & 0 & 4,189 \\
\hline \multicolumn{6}{|l|}{ Male (dummy) } \\
\hline 2013 & 1,943 & 0.493 & 0.500 & 0 & 1 \\
\hline 2014 & 2,000 & 0.493 & 0.500 & 0 & 1 \\
\hline 2015 & 2,000 & 0.486 & 0.500 & 0 & 1 \\
\hline 2017 & 2,118 & 0.487 & 0.500 & 0 & 1 \\
\hline \multicolumn{6}{|l|}{ Household income } \\
\hline 2013 & 1,943 & 2.155 & 0.821 & 1 & 3 \\
\hline 2014 & 2,000 & 2.059 & 0.849 & 1 & 3 \\
\hline 2015 & 2,000 & 1.875 & 0.781 & 1 & 3 \\
\hline 2017 & 2,118 & 2.154 & 0.861 & 1 & 3 \\
\hline
\end{tabular}




\begin{tabular}{|l|c|c|c|c|c|}
\hline \multicolumn{1}{|c|}{ Variable } & N & Mean & Standard Deviation & Min & Max \\
\hline Age (years) & 1,915 & 36.264 & 12.304 & 18 & 64 \\
\hline 2013 & 2,000 & 36.079 & 12.450 & 18 & 64 \\
\hline 2014 & 1,920 & 35.851 & 12.182 & 18 & 64 \\
\hline 2015 & 2,049 & 35.929 & 12.689 & 18 & 64 \\
\hline 2017 & 1,942 & 4.406 & 1.426 & 1 & 13 \\
\hline Household size & 2,000 & 4.408 & 1.345 & 1 & 10 \\
\hline 2013 & 2,000 & 4.203 & 1.287 & 1 & 12 \\
\hline 2014 & 2,118 & 4.211 & 1.165 & 1 & 11 \\
\hline 2015 &
\end{tabular}

Source: Author's compilation from GEM dataset in 2013-2015 and 2017.

\section{Empirical results}

The effect of "general skills" and "specialized skills" on the probability of success of entrepreneurs is measured through the estimation of equation (3). The estimation of equation (3) is repeated for different year of survey because GEM datasets are not panel data. This estimation does not affect the generality of empirical results when GEM datasets are nationally representative. The results offer clear evidence that "general skills" and "specialized skills" have effects on the success of entrepreneurs, especially for the second aspect of "specialized skills". Tables $2 \mathrm{a}$ and $2 \mathrm{~b}$ present baseline specification (without control variables) and full model (with control variables). From the empirical results presented in table $2 \mathrm{a}$ and $2 b$, "general skills" and "specialized skills: aspect 1 "' hold consistently only for the years 2015 and 2017 in baseline and full model, while estimation between baseline and full model for the years 2013 and 2014 are not consistent. The difference between baseline and full model imply that the influences of entrepreneurs' characteristics and living conditions - measuring via control variables to dependent and independent variables might be the case. However, finding these further effects is not the main goal of this paper. Instead, this paper tries to focus on the major effect between "general skills", "specialized skills" and "balanced skills" on the probability of success of entrepreneurs under different patterns.

From tables $3 \mathrm{a}$ and $3 \mathrm{~b}$, the effect of "general skills" and "specialized skills" on probability of success of the entrepreneur are partly familiar when "general skills" and "specialized skills" do have positive effect on the probability. "General skills" - in the baseline model - affect positively the probability of success of entrepreneurs. Furthermore, including control variables in the baseline model does not change the result. However, because estimated coefficients are not statistically significant in the years 2013 and 2014, the policy makers based on this empirical result need to consider carefully the moderate influences of personal characteristics of entrepreneurs.

2 Specialized skills - Aspect 1 refers to the years of schooling in higher education institutions where the learner is specialized in different courses and sets of skills. 


\section{Articles}

Table 3a. Baseline estimation measuring the effect of general and specialized skills on the probability of the success of entrepreneurs

\begin{tabular}{|c|c|c|c|c|}
\hline Variable & 2013 & 2014 & 2015 & 2017 \\
\hline \multicolumn{5}{|l|}{ Dependent variable is established firm } \\
\hline General skills & $\begin{array}{l}0.055^{\star} \\
(0.029)\end{array}$ & $\begin{array}{c}0.024 \\
(0.025)\end{array}$ & $\begin{array}{c}0.161^{\star \star \star} \\
(0.043)\end{array}$ & $\begin{array}{l}-0.018 \\
(0.025)\end{array}$ \\
\hline Specialized skills: Aspect 1 & $\begin{array}{c}0.046^{* *} \\
(0.020)\end{array}$ & $\begin{array}{c}0.014 \\
(0.017)\end{array}$ & $\begin{array}{c}0.141^{* * *} \\
(0.029)\end{array}$ & $\begin{array}{c}-0.082^{* * *} \\
(0.017)\end{array}$ \\
\hline Specialized skills: Aspect 2 & $\begin{array}{c}0.839 * * * \\
(0.075)\end{array}$ & $\begin{array}{c}0.647^{* * *} \\
(0.067)\end{array}$ & $\begin{array}{c}0.389 * * * \\
(0.072)\end{array}$ & $\begin{array}{c}0.258^{* * *} \\
(0.070)\end{array}$ \\
\hline $\mathrm{N}$ & 1,943 & 2,000 & 2,000 & 2,118 \\
\hline Pseudo- $R^{2}$ & 0.106 & 0.057 & 0.041 & 0.045 \\
\hline Wald $x^{2}$ & 152.84 & 100.24 & 63.43 & 89.91 \\
\hline Robust estimation & Yes & Yes & Yes & Yes \\
\hline
\end{tabular}

Source: Author's estimation

Table 3b. The effect of general and specialized skills on the probability of the success of entrepreneurs

\begin{tabular}{|c|c|c|c|c|}
\hline Variable & 2013 & 2014 & 2015 & 2017 \\
\hline \multicolumn{5}{|l|}{ Dependent variable is established firm } \\
\hline General skills & $\begin{array}{c}0.044 \\
(0.0297)\end{array}$ & $\begin{array}{c}0.002 \\
(0.025)\end{array}$ & $\begin{array}{c}0.101^{* * *} \\
(0.039)\end{array}$ & $\begin{array}{l}-0.008 \\
(0.026)\end{array}$ \\
\hline Specialized skills: Aspect 1 & $\begin{array}{c}0.031 \\
(0.0212)\end{array}$ & $\begin{array}{c}-0.013 \\
(0.0181)\end{array}$ & $\begin{array}{c}0.081^{* * \star} \\
(0.028)\end{array}$ & $\begin{array}{c}-0.073^{\star \star \star} \\
(0.019)\end{array}$ \\
\hline Specialized skills: Aspect 2 & $\begin{array}{c}0.832^{\star * *} \\
(0.075)\end{array}$ & $\begin{array}{c}0.637^{* * *} \\
(0.069)\end{array}$ & $\begin{array}{c}0.379 * * * \\
(0.073)\end{array}$ & $\begin{array}{c}0.258^{* * *} \\
(0.074)\end{array}$ \\
\hline $\mathrm{N}$ & 1.943 & 2.000 & 1.920 & 2.118 \\
\hline Pseudo-R2 & 0.1094 & 0.069 & 0.070 & 0.08 \\
\hline Wald $\times 2$ & 159.10 & 115.27 & 130.59 & 142.13 \\
\hline Control variables included & Yes & Yes & Yes & Yes \\
\hline Robust estimation & Yes & Yes & Yes & Yes \\
\hline
\end{tabular}

Source: Author's estimation

As can be seen from table 3b, "Specialized skills - Aspect 1" has negatively affected the probability of the success of entrepreneurs only in the year 2017 implying a complex effect of learning outcomes at higher education institutions. With the current curriculums at the Vietnamese higher education institutions, the outcomes of the training course aimed to arm students with entrepreneurial skills are hard to find. These curriculums are just 


\section{Articles}

outdated combination of many subjects that might reduce the time for studying specialized skills relevant to the need of becoming entrepreneurs. There is very little information from the GEM dataset on the performance of learning outcomes at higher education institutions; then it is difficult to analyze further this issue.

"Specialized skills - Aspect 2", as expected, affect positively the probability of success of entrepreneurs. The empirical results in baseline and full models are identical; and this exposes the determinant role of this set of skills to the probability. Entrepreneurs having more of this type of skills can have higher probability to successfully establish a firm. Additionally, these skills might increase the chance of longer survival and greater success of entrepreneurs' firms. Indeed, the existence of firms might be longer if entrepreneurs do have such type of specialized skills. However, the effect of this type of skills on the probability reduced from the year 2013 to the
Learning Outcomes and the Success of Entrepreneurs:

The Case of Vietnam

year 2017 after including control variables into these models. This means that "specialized skills - aspect 2" does not have consistent influences on the chance of entrepreneurs to have a successful business.

Estimating the probability of success of entrepreneurs in different levels of specialized skills provides further information about the determinant of "specialized skills - aspect 2" to the probability of success of entrepreneurs. An entrepreneur has much higher probability to succeed when he/her has more specialized skills. In the years of $2013-2015$ and 2017, the probability of success of entrepreneurs having only one specialized skill are $0.08,0.12,0.08$ and 0.23 respectively, while the probability of success of entrepreneurs having two specialized skills in the same period are 0.17 , $0.20,0.12$ and 0.27 respectively. Certainly, entrepreneurs having three specialized skills the have highest probability of success when the probabilities are $0.32,0.32,0.16$ and 0.32 respectively.

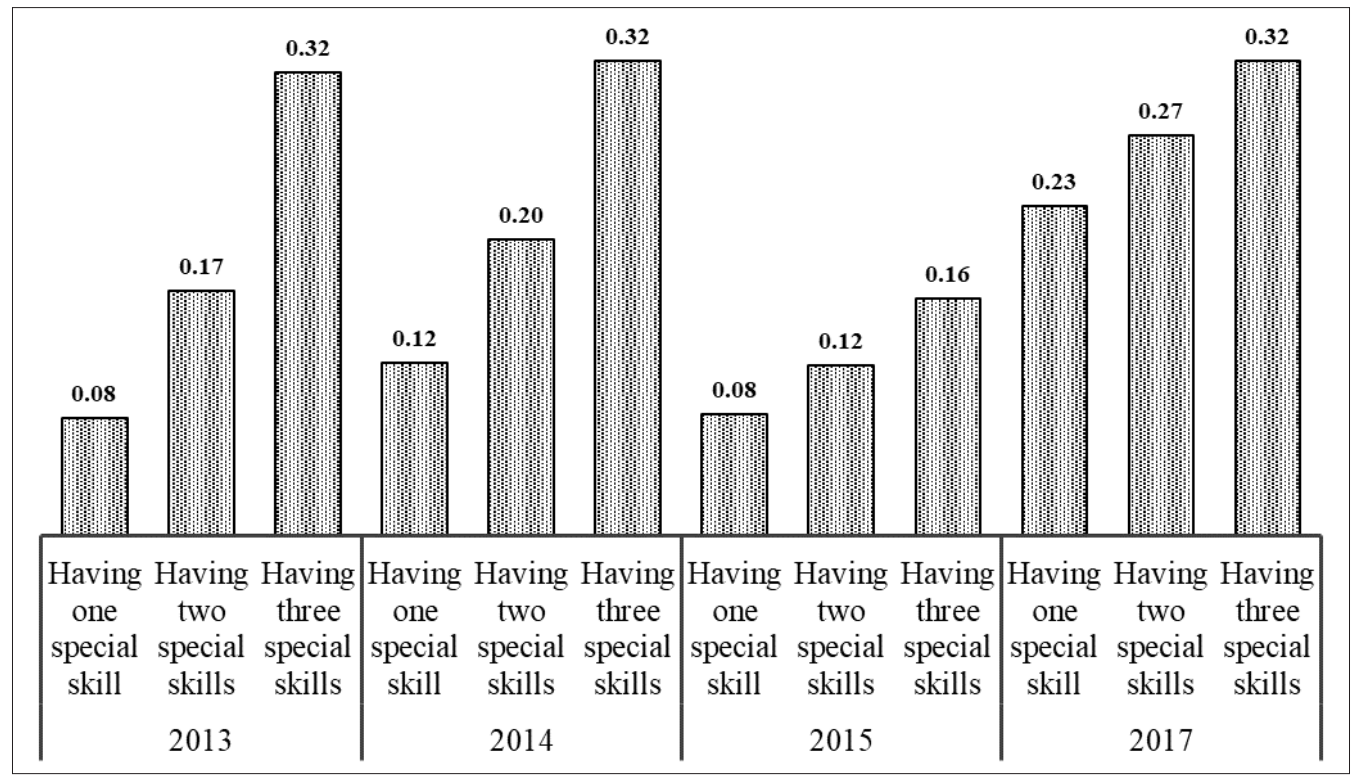

Figure 1. Predicted probability of success of entrepreneurs according to specialized skills Source: Author's estimation 


\section{Articles}

Interestingly, the gap of the probabilities in the years 2013 and 2014 are quite familiar while the other two years show the different similarities. The gap of the probabilities in the years 2013 and 2014 is larger than the gap in the years 2015 and 2017. This result implies the unobserved effects of the business environment and other unforeseen factors that cannot be captured within this model. Although having specialized skills might increase the chance of being successful, it cannot guarantee that entrepreneurs will take these advantages to gain success. Their success in doing business have been affected by the other factors that they might not estimate.

Table 4a. Baseline estimation for balanced skills and the success of entrepreneurs

\begin{tabular}{|c|c|c|c|c|}
\hline Variable & 2013 & 2014 & 2015 & 2017 \\
\hline \multicolumn{5}{|c|}{ Dependent variable is a binary variable where it is 1 in the case of an established firm and 0 otherwise } \\
\hline Balanced skills & $\begin{array}{c}1.388^{\star * \star} \\
(0.150)\end{array}$ & $\begin{array}{c}0.454^{\star * \star} \\
(0.099)\end{array}$ & $\begin{array}{c}0.976^{\star \star \star} \\
(0.127)\end{array}$ & $\begin{array}{r}-0.186^{* * *} \\
(0.079)\end{array}$ \\
\hline $\mathrm{N}$ & 1,465 & 1,637 & 1,877 & 2,188 \\
\hline Pseudo-R2 & 0.075 & 0.018 & 0.044 & 0.002 \\
\hline Wald $x^{2}$ & 85.34 & 20.9 & 59.06 & 5.48 \\
\hline Robust estimation & Yes & Yes & Yes & Yes \\
\hline
\end{tabular}

Source: Author's estimation

Table 4b. Balanced skill and the success of entrepreneurs

\begin{tabular}{|l|c|c|c|c|}
\hline \multicolumn{1}{|c|}{ Variable } & $\mathbf{2 0 1 3}$ & $\mathbf{2 0 1 4}$ & $\mathbf{2 0 1 5}$ & $\mathbf{2 0 1 7}$ \\
\hline Dependent variable is a binary variable where it is 1 in the case of an established firm and 0 otherwise \\
\hline Balanced skills & $\begin{array}{r}1.336^{* * *} \\
(0.156)\end{array}$ & $\begin{array}{c}0.341^{* * *} \\
(0.105)\end{array}$ & $\begin{array}{c}0.780^{* * *} \\
(0.130)\end{array}$ & $\begin{array}{c}-0.094 \\
(0.091)\end{array}$ \\
\hline N & 1.465 & 1.637 & 1.799 & 2.118 \\
\hline Pseudo-R2 & 0.077 & 0.03 & 0.08 & 0.04 \\
\hline Wald X2 & 87.47 & 40.65 & 138.27 & 72.28 \\
\hline Control variables included & Yes & Yes & Yes & Yes \\
\hline Robust estimation & Yes & Yes & Yes & Yes \\
\hline Note: - Numbers in parentheses are standard error; ${ }^{* * *}$ statistical significance at 1\%. \\
\hline
\end{tabular}

Source: Author's estimation

From table $4 \mathrm{a}$ and $4 \mathrm{~b}$, the effect of balanced skills on the probability of the success of entrepreneurs is positive, except for 2017. When including control variables into the regression model, the sign of estimated coefficients of balanced skills in the year
2013 - 2015 remain the same but the value of these coefficients changed slightly. The estimated coefficient in the year 2017 is not statistically significant when adding control variables; it means that the negative sign of 


\section{Articles}

this coefficient in the baseline model might not reflect the true effect.

Investing in further skills in having balanced skills does increase the chance of success of entrepreneurs. From table $4 \mathrm{~b}$, the higher investment in balanced skills might increase the probability of success of entrepreneurs by around $1.34 \%, 0.34 \%$, and $0.78 \%$ in the years 2013, 2014 and 2015 respectively. It is said that because of lacking information on the mechanism of transferring gaining balanced skills to the success of entrepreneurs in the GEM datasets but based on the empirical result the implication is that entrepreneurs having a clear and strategic investment in balanced skills can increase their chance to succeed. Furthermore, this empirical result also implies to policy makers that they should consider the idea to harmonize courses
Learning Outcomes and the Success of Entrepreneurs:

The Case of Vietnam

providing entrepreneurial skills to students at the schools and universities rather than only at the higher education institutions.

From figure 2, the predicted probabilities of success of entrepreneurs in different values of balanced skills are increasing when entrepreneurs have higher value of balanced skills. Entrepreneurs having the highest balanced skills might increase their chance to have successful business by $45 \%$, $24 \%$ and $40 \%$ in the years of 2013, 2014 and 2015 respectively, while entrepreneurs having the lowest balanced skills only can increase their chance by $7 \%, 8 \%$ and $3 \%$ in the years of 2013, 2014 and 2015 respectively. The predictions in the year of 2017 are not interpreted because of the insignificance of the estimated coefficient.

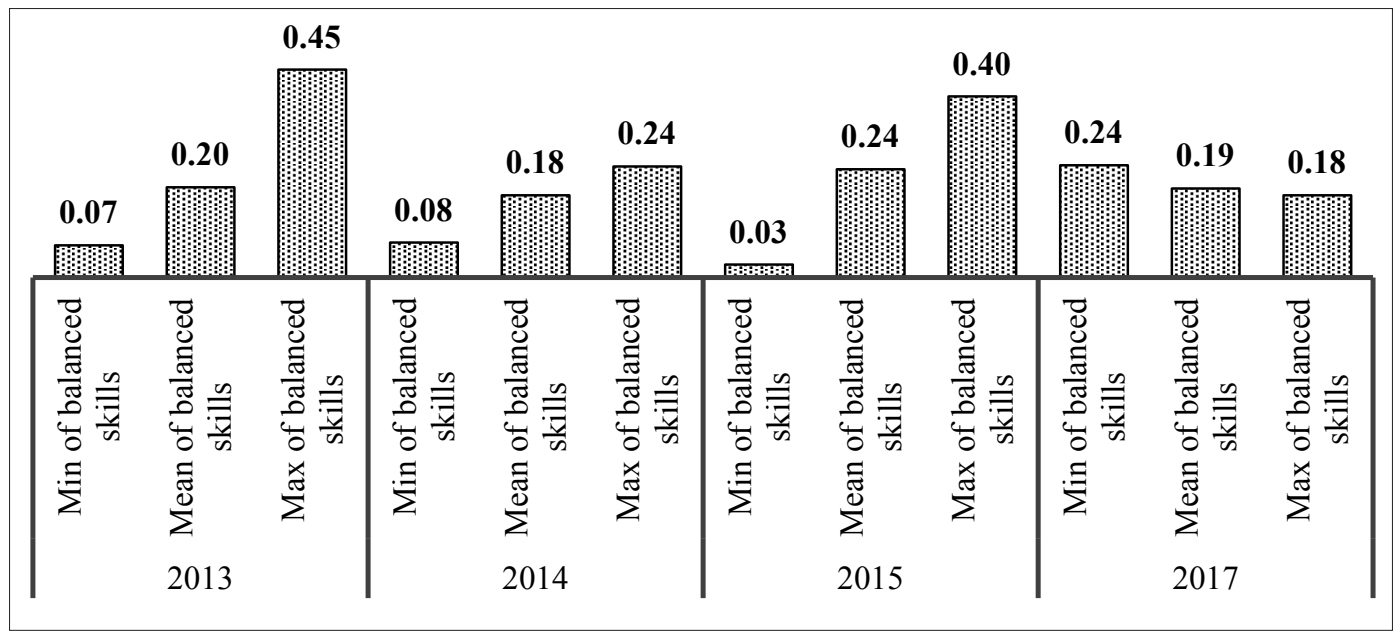

Figure 2. Predicted probability of success of entrepreneurs according to the level of balanced skills

Source: Author's estimation

\section{Discussion}

By analyzing the result, it has been found that general and specialized skills have affected considerably the probability of entrepreneurs' success in the context of
Vietnam. Indeed, entrepreneurial skills affect strongly the probability of entrepreneurs' success more than specialized skills obtained from higher education and general skills gained from schools. Additionally, gaining 


\section{Articles}

balanced skills is likely to help entrepreneurs to achieve a higher chance of success in their career path. The result of the research is in line, using Lazear (2004) as a major research tool, with Chen and Thompson (2016) where the two researchers find that balanced skills are positively correlated with entrepreneurs' success; and Hsieh et al. (2017) where these research find that investing in balanced skills makes individuals more likely to become successful entrepreneurs.

To identify the relationship between general, specialized skills and the probability of entrepreneurs' success using the GEM datasets is a first attempt. There are several studies conducted for the case of Vietnam, for instance Q. A. Nguyen and Mort (2016), Ramamurthy (2001) and X. T. Nguyen (2020) among others, but these studies utilize different methods or datasets. This paper and the other research are quite similar in measurements of the two types of skills, especially for general and the first aspect of specialized skills. The difference between this paper and the other is utilizing Lazear's (2004) theory and employing the GEM datasets to provide a quantitative analysis on the relationship between the two types of skills to the chance of success of entrepreneurs. However, the GEM datasets are not conducted mainly to evaluate the effect of entrepreneurs' skills on their success, but the effect of investing in balanced skills on the probability of entrepreneurs' success is in line with the other studies. The paper's findings also confirm that in the context of Vietnam, the effect of investing in balanced skills on the success of entrepreneurs should be considered with care because the unstable estimated coefficient of the balanced skills variable.

In the case of the sample size of GEM datasets, the general ability of outcomes is limited by the number of observations and the problem of the representative sampling process. The GEM datasets for Vietnam only cover several provinces in Vietnam and each province in the sample does not represent all the other excluded provinces. Aware of this limitation, policy implications from this paper for policy makers should be considered as one of reliable information sources. In addition, because of data limitation, this paper is not able to analyze the effect of the institutional context of Vietnam as moderator of the relationship between the two types of skills and the success of entrepreneurs.

\section{Conclusion}

A popular economic theory of entrepreneurship shows that entrepreneurs tend to invest more in their skills to increase their chance of being successful. More recently, researchers have started to employ Lazear's (2004) theory to predict the effect of balanced skills on the likelihood of entrepreneurship. Despite these clear-cut theoretical predictions, empirical estimations do not show the different types of skills that entrepreneurs should care about if they wish to have a higher probability of success. This paper has presented an empirical work on the choices of skill balance and the success of entrepreneurs which can analyze the effect of different types of skills on the probability of success of entrepreneurship.

Balanced skills in this paper are a combination of general skills - which entrepreneurs obtain from their formal schools - and specialized skills - which entrepreneurs obtain from higher education institutions and their experience. These measures have the advantage of occurring prior to the success of entrepreneurs, but they might have the problem of endogeneity. 


\section{Articles}

This paper leaves it to the future research to investigate other possible variables which might eliminate endogeneity problems.

To conclude, this paper proposed a novel linkage between balanced skills and the success of entrepreneurs, which casts a new light on the theories of entrepreneurship. The paper also carries implications for scholars and policy makers about the linkage between general skills, specialized skills and the success of entrepreneurs. The implication is that policy makers might take further action in the field to promote entrepreneurial skills to students in their early life to help them have a higher probability of being successful entrepreneurs. Additionally, policy implications from this paper are that entrepreneurs and higher education institutions should have better linkage in order to develop courses providing rich sources of entrepreneurial skills to learners. Further research should address the moderating effect of the institutional context in Vietnam to the relationship between the two types of skills and the success of entrepreneurs, and compare Vietnamese cases and other transition economies as well.

\section{References}

Åstebro, T., \& Thompson, P. (2011). Entrepreneurs, Jacks of all trades or Hobos? Research policy, 40(5), 637-649.

Astebro, T. B., Chen, J., \& Thompson, P. (2008). Stars and misfits: A theory of occupational choice. Management Science, 57(11), 1999-2017.

Benzing, C., Chu, H. M., \& Bove, R. (2005). The motivation, problems, and perceived success of entrepreneurs in Romania. Journal of the Academy of Business Administration, 10(1/2), 73-88.

Bessant, J., \& Tidd, J. (2007). Innovation and entrepreneurship: John Wiley \& Sons.
Learning Outcomes and the Success of Entrepreneurs:

The Case of Vietnam

Boldureanu, G., Ionescu, A. M., Bercu, A.-M., Bedrule-Grigoruţă, M. V., \& Boldureanu, D. (2020). Entrepreneurship education through successful entrepreneurial models in higher education institutions. Sustainability, 12(3), 1267.

Bosma, N., \& Schutjens, V. (2011). Understanding regional variation in entrepreneurial activity and entrepreneurial attitude in Europe. The Annals of regional science, 47(3), 711-742.

Boynton, A. C., \& Zmud, R. W. (1984). An assessment of critical success factors. Sloan management review, 25(4), 17-27.

Chamberlain, G. (1980). Analysis of covariance with qualitative data. The Review of Economic Studies, 47(1), 225-238.

Chen, L.-W., \& Thompson, P. (2016). Skill balance and entrepreneurship evidence from online career histories. Entrepreneurship Theory and Practice, 40(2), 289-305.

Chu, H. M., Benzing, C., \& McGee, C. (2007). Ghanaian and Kenyan entrepreneurs: A comparative analysis of their motivations, success characteristics and problems. Journal of developmental entrepreneurship, 12(03), 295-322.

Dickson, P. H., Solomon, G. T., \& Weaver, K. M. (2008). Entrepreneurial selection and success: does education matter? Journal of small business and enterprise development, 15(2), 239-258.

Drucker, P. (2014). Innovation and entrepreneurship: Routledge.

Elfenbein, D. W., Hamilton, B. H., \& Zenger, T. R. (2010). The small firm effect and the entrepreneurial spawning of scientists and engineers. Management Science, 56(4), 659681.

Folta, T. B., Delmar, F., \& Wennberg, K. (2010). Hybrid entrepreneurship. Management Science, 56(2), 253-269. 
Global Entrepreneurship Monitor. (2013). The Global Expert Survey 2013. Retrieved from Hanoi, Vietnam:

Global Entrepreneurship Monitor. (2015). The Global Expert Survey 2015. Retrieved from Hanoi, Vietnam:

Global Entrepreneurship Monitor. (2017). The Global Expert Survey 2017/2018. Retrieved from Hanoi, Vietnam:

Global Entrepreneurship Monitor, \& VCCl. (2018). Report Global Entrepreneurship Monitor Vietnam 2017/2018. Retrieved from Hanoi, Vietnam:

Guiso, L., Pistaferri, L., \& Schivardi, F. (2021). Learning entrepreneurship from other entrepreneurs? Journal of Labor Economics, 39(1), 135-191.

Hébert, R. F., \& Link, A. N. (2006). The entrepreneur as innovator. The Journal of Technology Transfer, 31(5), 589-597.

Hsieh, C., Parker, S. C., \& van Praag, C. M. (2017). Risk, balanced skills and entrepreneurship. Small Business Economics, 48(2), 287-302.

Krasniqi, B. A. (2012). Building an expanded small firm growth model in a transitional economy: Evidence on fast growing firms. Journal of East-West Business, 18(3), 231-273.

Krasniqi, B. A., \& Tullumi, M. (2013). What perceived success factors are important for smalll business owners in a transition economy? International Journal of Business and Management Studies, 5(2), 21-32.

Laguna-Sánchez, P., Abad, P., de la FuenteCabrero, C., \& Calero, R. (2020). A university training programme for acquiring entrepreneurial and transversal employability skills, a students' assessment. Sustainability, 12(3), 796.

Lazear, E. P. (2004). Balanced skills and entrepreneurship. American Economic Review, 94(2), 208-211.
Lucas Jr, R. E. (1978). On the size distribution of business firms. The Bell Journal of Economics, 9(2), 508-523.

Mohanty, S. K. (2005). Fundamentals of entrepreneurship: PHI Learning Pvt. Ltd.

Nanda, R., \& Sørensen, J. B. (2010). Workplace peers and entrepreneurship. Management Science, 56(7), 1116-1126.

Nandan, H. (2013). Fundamentals of entrepreneurship: PHI Learning Pvt. Ltd.

Nguyen, A. T., Do, T. H. H., Vu, T. B. T., Dang, K. A., \& Nguyen, H. L. (2019). Factors affecting entrepreneurial intentions among youths in Vietnam. Children and Youth Services Review, 99, 186-193.

Nguyen, Q. A., \& Mort, G. S. (2016). Economic reform and entrepreneurship in Vietnam: $A$ policy perspective. In J. Ateljevic \& J. Trivic (Eds.), Economic development and entrepreneurship in transition economies (pp. 109-127). Switzerland: Springer.

Nguyen, T. H., Alam, Q., \& Prajogo, D. (2008). State and Market relationships: Public financial policy support for SMEs growth in Vietnam. International Review of Business Research Papers, 4(2), 203-216.

Nguyen, X. T. (2020). Factors Affecting Entrepreneurial Decision of Nascent Entrepreneurs Belonging Generation $Y$ in Vietnam. The Journal of Asian Finance, Economics, and Business, 7(8), 407-417.

Pratt, V. (2001). Sharing business skills in Kenya. Center for International Private Enterprise. Washington DC www. cipe. org.

Prentice, R. L., \& Pyke, R. (1979). Logistic disease incidence models and case-control studies. Biometrika, 66(3), 403-411.

Ramamurthy, B. (2001). The Non-state Manufacturing Sector in Vietnam 1991-97: An Analysis of the Winners. In P. Ronnas \& B. Ramamurthy (Eds.), Entrepreneurship in Vietnam. Copenhagen: Nordic Institute of Asian Studies: Institute of Asian Studies. 


\section{Articles}

Rockart, J. F. (1979). Chief executives define their own data needs. Harvard Business Review, 57(2), 81-93.

Ronnas, P. (2001). Introduction. In P. Ronnas \& B. Ramamurthy (Eds.), Entrepreneurship in Vietnam. Copenhagen: Nordic Institute of Asian Studies: Institute of Asian Studies.

Ronnas, P., \& Ramamurthy, B. (2001). Summary and Conclusions. In P. Ronnas \& B. Ramamurthy (Eds.), Entrepreneurship in Vietnam. Copenhagen: Nordic Institute of Asian Studies: Institute of Asian Studies.

Rosen, S. (1982). Authority, control, and the distribution of earnings. The Bell Journal of Economics, 13(2), 311-323.

Santarelli, E., \& Tran, H. T. (2013). The interplay of human and social capital in shaping entrepreneurial performance: the case of Vietnam. Small Business Economics, 40(2), 435-458.

Saraph, J. V., Benson, P. G., \& Schroeder, R. G. (1989). An instrument for measuring the critical factors of quality management. Decision sciences, 20(4), 810-829.
Learning Outcomes and the Success of Entrepreneurs:

The Case of Vietnam

Schumpeter, J. A. (1982). The" Crisis" in Economics-Fifty Years Ago. Journal of Economic Literature, 20(3), 1049-1059.

Shapero, A., \& Sokol, L. (1982). The social dimensions of entrepreneurship. University of Illinois at Urbana-Champaign's Academy for Entrepreneurial Leadership Historical Research Reference in Entrepreneurship.

Ulhøi, J. P. (2005). The social dimensions of entrepreneurship. Technovation, 25(8), 939946.

Velilla, J. (2018). The entrepreneurial activity using GEM data: evidence for Spain (national and regional) and for Europe.

Viramgami, H. S. (2007). Fundamentals of entrepreneurship: APH Publishing.

Welter, F., \& Smallbone, D. (2011). Institutional perspectives on entrepreneurial behavior in challenging environments. Journal of Small Business Management, 49(1), 107-125.

Young, S. (2009). Entrepreneurship in Vietnam. In R. J. Pech (Ed.), Stories of Entrepreneurial Courage, Audacity and Genius (pp. 156-166). Sydney: Pearson Education. 